CRYSTALLOGRAPHIC COMMUNICATIONS

ISSN 2056-9890

Received 18 March 2016

Accepted 19 March 2016

Edited by W. T. A. Harrison, University of Aberdeen, Scotland

‡ Additional correspondence author, e-mail: dyoung1@usc.edu.au.

Keywords: crystal structure; triazolyl; conformation; DFT; Hirshfeld surface.

CCDC reference: 1469592

Supporting information: this article has supporting information at journals.iucr.org/e

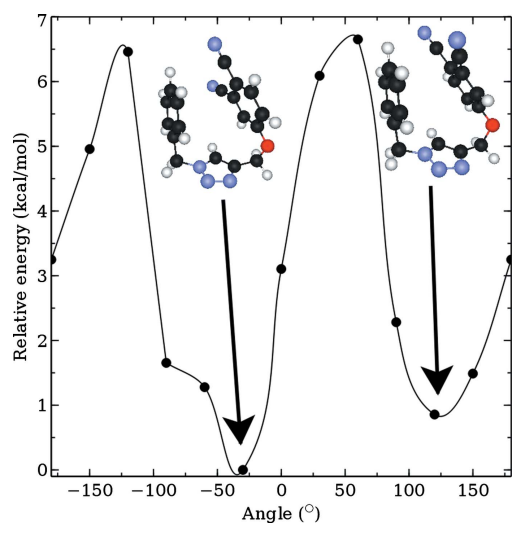

OPEN $\odot$ ACCESS

\section{4-[(1-Benzyl-1H-1,2,3-triazol-4-yl)methoxy]- benzene-1,2-dicarbonitrile: crystal structure, Hirshfeld surface analysis and energy-minimization calculations}

\author{
Norzianah Shamsudin, ${ }^{a}$ Ai Ling Tan, ${ }^{a}$ David J. Young, ${ }^{b} \ddagger$ Mukesh M. Jotani, ${ }^{c}$ \\ A. Otero-de-la-Roza ${ }^{d, e}$ and Edward R. T. Tiekink ${ }^{f_{*}}$
}

a'Faculty of Science, Universiti Brunei Darussalam, Jalan Tungku Link BE 1410, Negara Brunei Darussalam, ${ }^{\mathbf{b}}$ Faculty of
Science, Health, Education and Engineering, University of the Sunshine Coast, Maroochydore DC, Queensland 4558,
Australia, 'Department of Physics, Bhavan's Sheth R. A. College of Science, Ahmedabad, Gujarat 380 001, India,
${ }^{\mathbf{d}}$ National Institute for Nanotechnology, National Research Council of Canada, 11421 Saskatchewan Drive, Edmonton,
Alberta, T6G 2M9, Canada, ${ }^{\mathbf{e}}$ Department of Chemistry, University of British Columbia, Okanagan, 3247 University Way,
Kelowna, British Columbia, V1V 1V7, Canada, and ' Research Centre for Crystalline Materials, Faculty of Science and
Technology, Sunway University, 47500 Bandar Sunway, Selangor Darul Ehsan, Malaysia. *Correspondence e-mail:
edwardt@sunway.edu.my

In the solid state, the title compound, $\mathrm{C}_{18} \mathrm{H}_{13} \mathrm{~N}_{5} \mathrm{O}$, adopts a conformation whereby the phenyl ring and methoxy-benzene-1,2-dicarbonitrile residue (r.m.s. deviation of the 12 non-H atoms $=0.041 \AA$ ) lie to opposite sides of the central triazolyl ring, forming dihedral angles of 79.30 (13) and $64.59(10)^{\circ}$, respectively; the dihedral angle between the outer rings is $14.88(9)^{\circ}$. This conformation is nearly $7 \mathrm{kcal} \mathrm{mol}^{-1}$ higher in energy than the energy-minimized structure which has a syn disposition of the outer rings, enabling intramolecular $\pi-\pi$ interactions. In the crystal, methylene-C $-\mathrm{H} \cdots \mathrm{N}$ (triazolyl) and carbonitrile$\mathrm{N} \cdots \pi$ (benzene) interactions lead to supramolecular chains along the $a$ axis. Supramolecular layers in the $a b$ plane arise as the chains are connected by benzene-C $-\mathrm{H} \cdots \mathrm{N}$ (carbonitrile) interactions; layers stack with no directional interactions between them. The specified intermolecular contacts along with other, weaker contributions to the supramolecular stabilization are analysed in a Hirshfeld surface analysis.

\section{Chemical context}

We have previously reported the crystal structure of bis [(phenylmethanamine- $\kappa \mathrm{N})-\left(\right.$ phthalocyaninato- $\left.\kappa^{4} N\right)$ zinc $]$ phenylmethanamine trisolvate (Shamsudin et al., 2015) for use as a light-harvesting dye in dye-sensitized solar cells (DSSCs) (Kitamura et al., 2004, Nazeeruddin et al., 2001). Benzylamine was investigated as a solvent to assist coating $\mathrm{TiO}_{2}$ nanoparticles with the highly insoluble zinc phthalocyanine. Another strategy for solubilizing phthalocyanine dyes is to append solubilizing groups to these large, aromatic structures (Mack et al., 2006). Phthalocyanines are somewhat unreactive and so this is most easily done by modifying the precursor phthalonitriles. Unsymmetrical phthalocyanines (e.g. tetrarather than octa-substituted) can yield constitutional isomers, but are more soluble (Eberhart \& Hanack, 1997) and have a greater dipole moment which can make attractive molecules for non-linear optical applications (Tian et al., 1997). A particularly versatile and reliable reaction for the synthesis of analogues is the azide-alkyne Huisgen cycloaddition - the best known and most widely used reaction in the 'click chemistry' 
stable (Kolb et al., 2001). We therefore prepared 3-(prop-2-yn1-yloxy)phthalonitrile by the $\mathrm{S}_{\mathrm{N}} \mathrm{Ar}$ reaction of propagyl alcohol and 4-nitrophthalonitrile (Jan et al., 2013) and used this as a precursor for the synthesis of the title molecule (I), the structure of which is described herein along with a Hirshfeld surface analysis and the results of energy-minimization calculations.

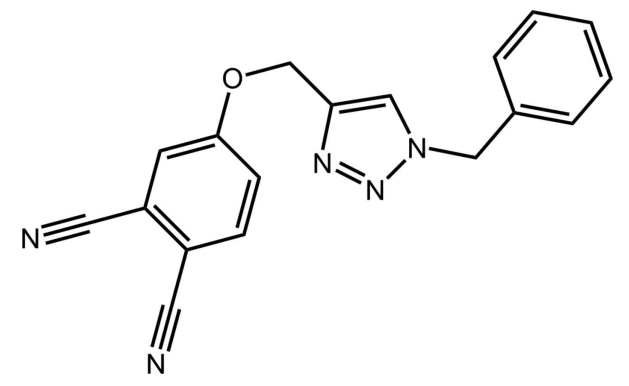

\section{Structural commentary}

The central five-membered triazolyl ring in (I), Fig. 1, is strictly planar with the r.m.s. deviation for the five atoms being $0.003 \AA$. The phenyl ring of the N-bound benzyl group is almost perpendicular to this plane, forming a dihedral angle of $79.30(13)^{\circ}$. The 12 atoms comprising the methoxy-benzene1,2-dicarbonitrile residue are almost co-planar with a r.m.s. deviation of $0.041 \AA$; the maximum and minimum deviations are -0.085 (2) and 0.038 (2) $\AA$ for atoms $\mathrm{C} 10$ and $\mathrm{C} 12$, respectively. Within the triazolyl ring, the $\mathrm{N} 2-\mathrm{N} 3$ and $\mathrm{C} 1-$ C2 bond lengths of 1.322 (3) and 1.367 (3) $\AA$, respectively, are consistent with considerable double-bond character in each of these bonds, i.e. consistent with the electronic structure shown in the Scheme. The methoxy-benzene-1,2-dicarbonitrile residue lies to the opposite side of the central ring to the benzyl residue and forms a dihedral angle of $64.59(10)^{\circ}$ with the triazolyl ring. The overall shape of the molecule is thus best described as a step with a dihedral angle between the outer rings of $14.62(12)^{\circ}$, consistent with these groups being approximately parallel.

\section{Supramolecular features}

The molecular packing in the crystal leads to supramolecular chains along the $a$ axis, formed through the agency of methylene-C10-H $\cdots \mathrm{N} 3$ (triazolyl) interactions involving both methylene-H atoms, which both link to N3 (Table 1). Encompassed within the chains are carbonitrile-

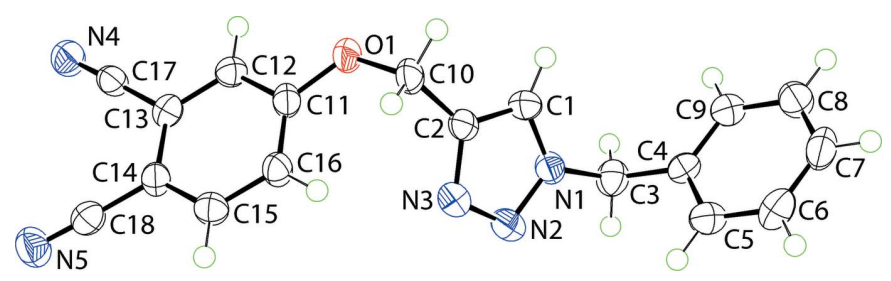

Figure 1

The molecular structure of (I), showing the atom-labelling scheme and displacement ellipsoids at the $70 \%$ probability level.
Table 1

Hydrogen-bond geometry $\left(\AA,^{\circ}\right)$.

$C g 1$ is the centroid of the $\mathrm{C} 11-\mathrm{C} 16$ ring.

\begin{tabular}{|c|c|c|c|c|}
\hline$D-\mathrm{H} \cdots A$ & $D-\mathrm{H}$ & $\mathrm{H} \cdots A$ & $D \cdots A$ & $D-\mathrm{H} \cdots A$ \\
\hline $\mathrm{C} 10-\mathrm{H} 10 A \cdots \mathrm{N} 3^{\mathrm{i}}$ & 0.99 & 2.50 & $3.468(3)$ & 167 \\
\hline $\mathrm{C} 10-\mathrm{H} 10 B \cdots \mathrm{N} 3^{\mathrm{ii}}$ & 0.99 & 2.53 & $3.477(3)$ & 161 \\
\hline $\mathrm{C} 12-\mathrm{H} 12 \cdots \mathrm{N} 4^{\mathrm{iii}}$ & 0.95 & 2.47 & $3.353(3)$ & 155 \\
\hline $\mathrm{C} 18-\mathrm{N} 5 \cdots C g 1^{\mathrm{iv}}$ & $1.15(1)$ & $3.81(1)$ & $3.853(2)$ & $83(1)$ \\
\hline
\end{tabular}

N5 $\cdots \pi$ (benzene) interactions, Table 1 . The chains are connected into supramolecular layers in the $a b$ plane by benzene-C12-H $\cdots \mathrm{N} 4$ (carbonitrile) interactions across a centre of inversion so that ten-membered $\left\{\cdots \mathrm{HC}_{3} \mathrm{~N}\right\}_{2}$ synthons are formed, Fig. 2 and Table 1. Layers inter-digitate along the $c$ axis but do not form contacts within the standard distance criteria (Spek, 2009), Fig. 3.

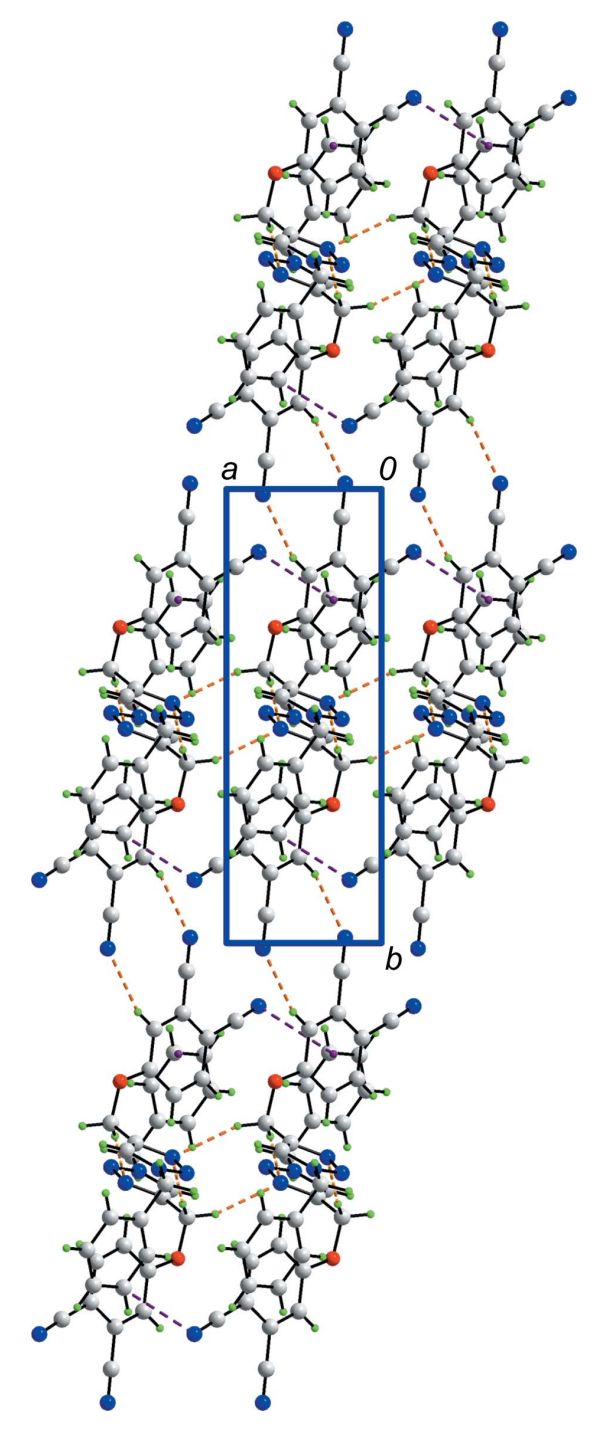

Figure 2

A view of the supramolecular layer in the $a b$ plane in (I). The layer is sustained by $\mathrm{C}-\mathrm{H} \cdots \mathrm{N}$ and $\mathrm{C}-\mathrm{H} \cdots \mathrm{N}$ interactions shown as orange and purple dashed lines, respectively. 


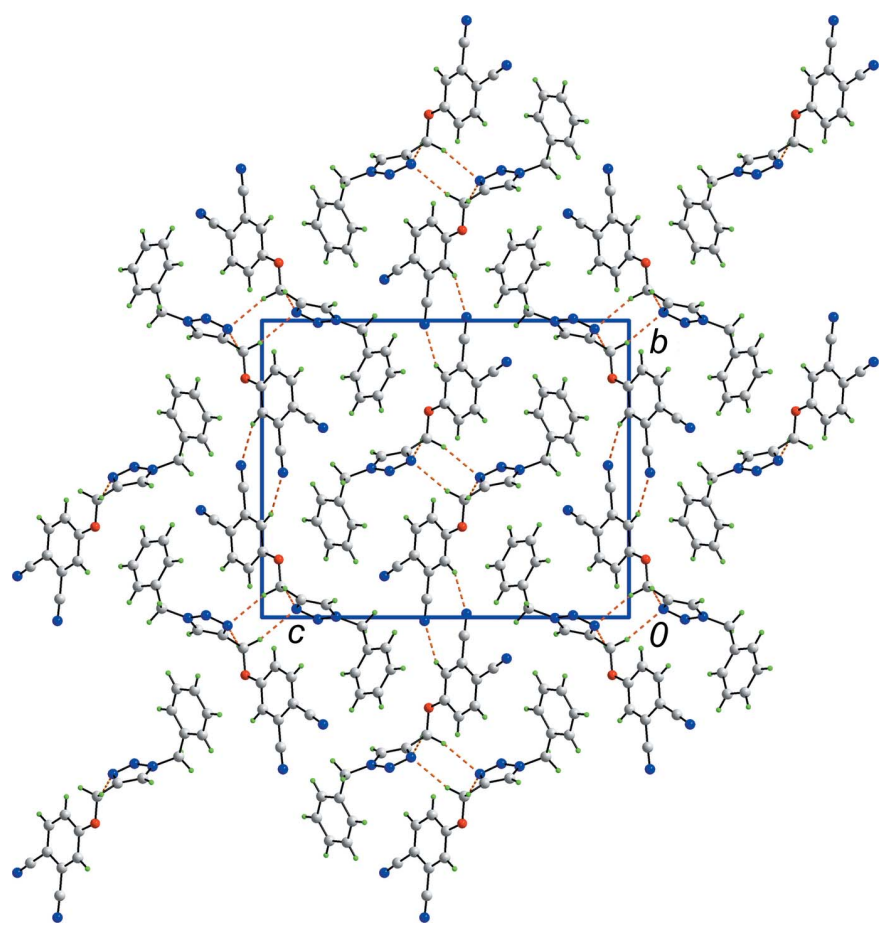

Figure 3

Unit cell contents for (I) shown in projection down the $a$ axis, showing the stacking of layers. The $\mathrm{C}-\mathrm{H} \cdots \mathrm{N}$ interactions are shown as orange dashed lines.

(a)

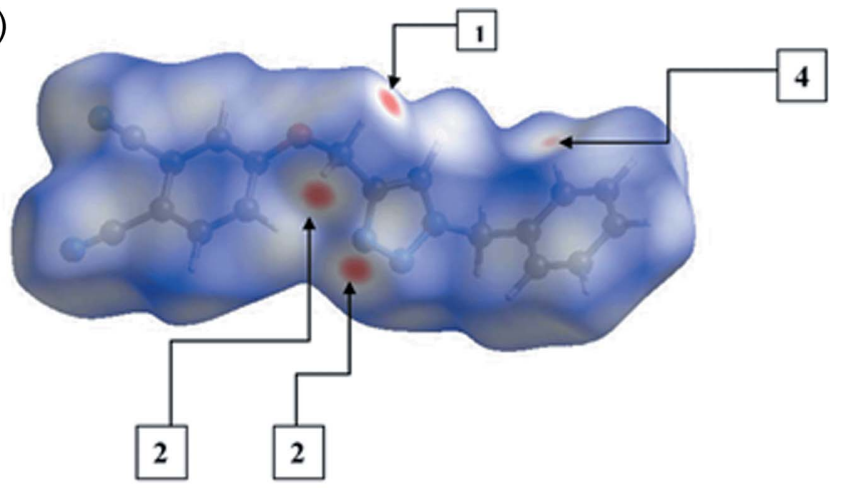

(b)

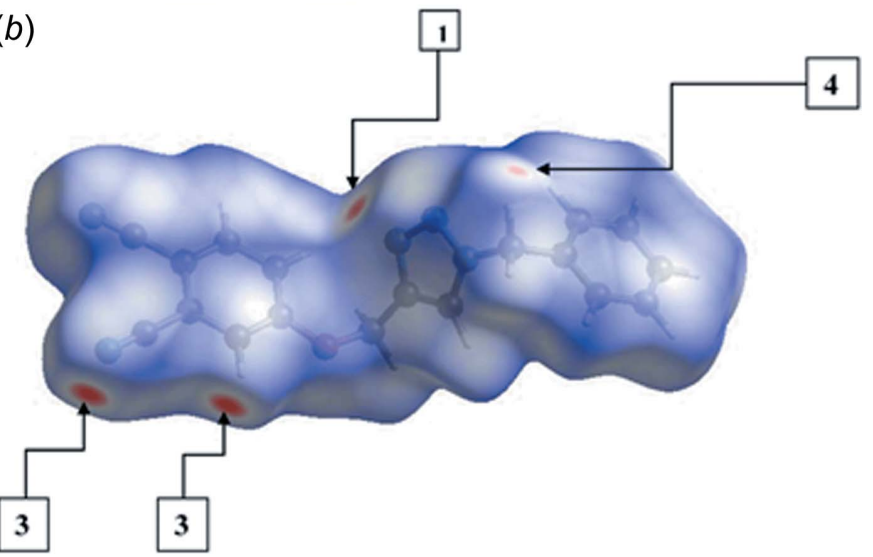

Figure 4

Two views of the Hirshfeld surfaces for (I) mapped over $d_{\text {norm }}$.
Table 2

Percentage contribution of the different intermolecular interactions to the Hirshfeld surface of (I).

\begin{tabular}{ll}
\hline Contact & $\%$ \\
\hline $\mathrm{H} \cdots \mathrm{H}$ & 24.7 \\
$\mathrm{~N} \cdots \mathrm{H} / \mathrm{H} \cdots \mathrm{N}$ & 35.7 \\
$\mathrm{C} \cdots \mathrm{H} / \mathrm{H} \cdots \mathrm{C}$ & 25.8 \\
$\mathrm{C} \cdots \mathrm{C}$ & 3.7 \\
$\mathrm{C} \cdots \mathrm{N}$ & 3.5 \\
$\mathrm{O} \cdots \mathrm{H} / \mathrm{H} \cdots \mathrm{O}$ & 3.2 \\
$\mathrm{C} \cdots \mathrm{O}$ & 2.7 \\
$\mathrm{~N} \cdots \mathrm{N}$ & 0.7 \\
\hline
\end{tabular}

\section{Hirshfeld surface analysis}

The program Crystal Explorer 3.1 (Wolff et al., 2012) was used to generate Hirshfeld surfaces mapped over $d_{\text {norm }}, d_{\mathrm{e}}$, curvedness and electrostatic potential. The electrostatic potential was calculated with TONTO (Spackman et al., 2008; Jayatilaka et al., 2005), integrated in Crystal Explorer, using the experimental geometry as the input. The electrostatic potentials were mapped on the Hirshfeld surface using the STO-3G basis set at the Hartree-Fock level of theory over a range \pm 0.075 au. The contact distances $d_{\mathrm{i}}$ and $d_{\mathrm{e}}$ from the Hirshfeld surface to the nearest atom inside and outside, respectively, enables the analysis of the intermolecular interactions through the mapping of $d_{\text {norm }}$. The combination of $d_{\mathrm{e}}$ and $d_{\mathrm{i}}$ in the form of a two-dimensional fingerprint plot (Rohl et al., 2008) provides a summary of the intermolecular contacts in the crystal.

The intermolecular interactions of the $\mathrm{C}-\mathrm{H} \cdots \mathrm{N}$ type involving triazolyl-N3 and carbonitrile-N4 atoms as hydrogenbond acceptors, and the $\mathrm{H} 10 A, \mathrm{H} 10 B$ and $\mathrm{H} 12$ hydrogen atoms as donors dominate the molecular packing. These interactions are easily recognized as bright-red spots, and are designated as 1,2 and 3 in a square box, respectively, on the Hirshfeld surface mapped with $d_{\text {norm }}$ in Fig. 4. The surface mapped with electrostatic potential, Fig. 5, highlights these interactions as blue and red regions corresponding to positive (donor) and negative (acceptor) electrostatic potentials. The presence of such dominating interactions are also evident from the two dimensional fingerprint (FP) plots, Fig. 6; relative contributions to the overall surface are given in Table 2.

The prominent pair of sharp spikes of equal lengths $\left(d_{\mathrm{e}}+d_{\mathrm{i}}\right.$ $\sim 2.25 \AA$ ) in the FP plot delineated into $\mathrm{N} \cdots \mathrm{H} / \mathrm{H} \cdots \mathrm{N}$ contacts, Fig. $6 d$, with a significant contribution to the overall Hirshfeld surface, i.e. $35.7 \%$ from $\mathrm{N} \cdots \mathrm{H} / \mathrm{H} \cdots \mathrm{N}$ contacts, and



Figure 5

Hirshfeld surface for (I) mapped over the electrostatic potential. 
Table 3

Dihedral angle $\left({ }^{\circ}\right)$ data for (I) and related literature structures ${ }^{a}$.

\begin{tabular}{|c|c|c|c|c|c|}
\hline Structure & Triazolyl/benzyl-phenyl & Triazolyl/O-benzene & Benzyl-phenyl/O $O$-benzene & CSD refcode ${ }^{b}$ & Reference \\
\hline (I) & $79.30(13)$ & $64.59(10)$ & $14.88(9)$ & - & This work \\
\hline (II) & $77.89(6)$ & $56.69(4)$ & $85.82(5)$ & CAKSAJ & Rostovtsev et al. (2002) \\
\hline (III) & $79.63(5)$ & $59.3695)$ & $85.56(6)$ & BEDREJ & Garcia et al. (2011) \\
\hline (V) & $82.03(9)$ & $26.57(9)$ & $83.63(8)$ & CIGRER & López-Ruiz et al. (2013) \\
\hline
\end{tabular}

Notes: (a) See Scheme 2 for chemical structures; (b) Groom \& Allen (2014).

the distinct pair of wings corresponding to $\mathrm{C} \cdot \mathrm{H} / \mathrm{H} \cdots \mathrm{C}$ contacts, Fig. $6 c$, with a $25.8 \%$ contribution, combined, have a greater effect on the molecular packing than the dispersive $\mathrm{H} \cdot \mathrm{H}$ contacts, Fig. $6 b$. The diminutive red spots on the surface mapped with $d_{\text {norm }}$, designated as 4 in a square box of Fig. 4, at the phenyl-C9 and methylene-H3B atoms, reflect the presence of short intermolecular $\mathrm{C} \cdots \mathrm{H}$ contacts $\left[\mathrm{C} 9 \cdots \mathrm{H} 3 B^{\mathrm{i}}=\right.$ $2.79 \AA$ for symmetry code: (i) $-1+x, y, z]$. The short intramolecular $\mathrm{H} \cdots \mathrm{H}$ contact between the benzene-H16 and Omethylene-H10 $A$ atoms $(\mathrm{H} 10 A \cdots \mathrm{H} 16=2.09 \AA)$ can be recognized from two neighbouring blue regions on the surface mapped with electrostatic potential in Fig. 5.

The presence of a comparatively weak $\mathrm{C}-\mathrm{N} \cdots \pi$ interaction can be viewed from the negative potential around the carbonitrile-N5 atom (red region) and the light-blue region around the phenyl ring in Fig. 5; the strength of this interaction is quantified as 3.7 and $3.5 \%$ relative contribution from $\mathrm{C} \cdots \mathrm{C}$ and $\mathrm{C} \cdots \mathrm{N}$ contacts to the surface. The small flat segments delineated by a blue outline in the surface mapped with curvedness, Fig. 7, and the small contribution from C..C contacts, i.e. $3.5 \%$, to the surface is consistent with the absence of significant $\pi-\pi$ stacking interactions in the structure. (a)

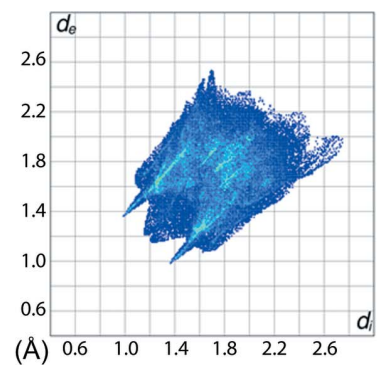

(b)

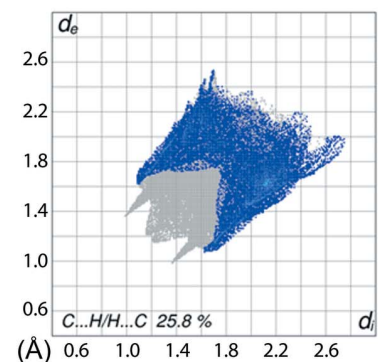

(c)

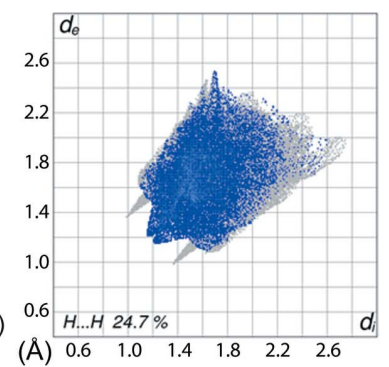

(d)

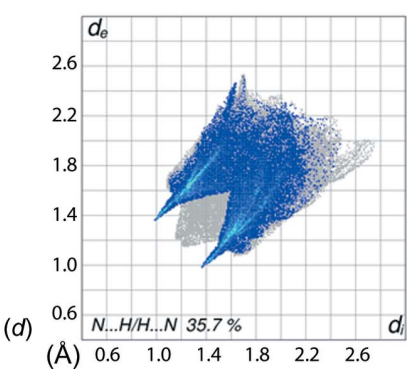

Figure 6

The two-dimensional fingerprint plots for (I): $(a)$ all interactions, and delineated into $(b) \mathrm{H} \cdots \mathrm{H},(c) \mathrm{C} \cdots \mathrm{H} / \mathrm{H} \cdots \mathrm{C}$, and $(d) \mathrm{N} \cdots \mathrm{H} / \mathrm{H} \cdots \mathrm{N}$ interactions.

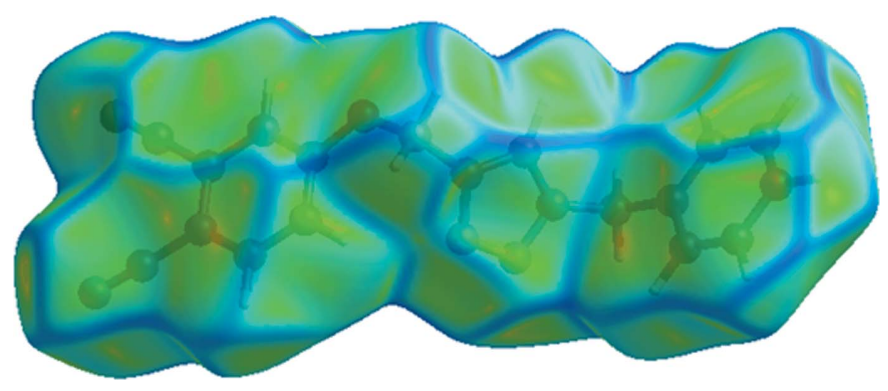

Figure 7

Hirshfeld surface for (I) mapped over curvedness.

\section{Database survey}

There are four closely related structures to (I) in the crystallographic literature (Groom \& Allen, 2014). The chemical structures of (II)-(V) are shown in Scheme 2, salient dihedral angles are given in Table 3 and a comparison between molecules is shown in Fig. 8. The similarity in the structures is seen in the relationship between the central triazolyl ring and pendent phenyl rings. By contrast to the conformation observed in (I), which was described above as anti with respect to the relative orientation of the $\mathrm{N}$ - and $\mathrm{C}$-bound residues to the central ring, a syn disposition is observed in each of (II) (Rostovtsev et al., 2002), (III) (Garcia et al., 2011) and (IV) (López-Ruiz et al., 2013). A similar but somewhat flattened syn relationship is observed in (V) (López-Ruiz et al., 2013) for which an intramolecular $\mathrm{O} \cdots \mathrm{N}$ contact of 2.745 (3) $\AA$ is noted between the ether-O and benzoxazole- $\mathrm{N}$ atoms. The difference in structures prompted energy-minimization calculations.

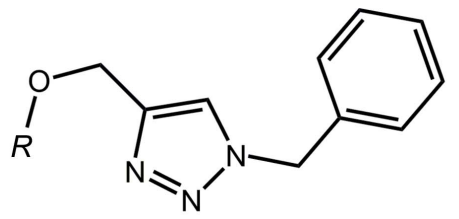

(II) $R=\mathrm{C}_{6} \mathrm{H}_{5}$; (III) $R=\mathrm{C}_{6} \mathrm{H}_{4} \mathrm{Me}-4$; (IV) $R=\mathrm{C}_{6} \mathrm{H}_{4} \mathrm{Br}-4$

(V) $R=$

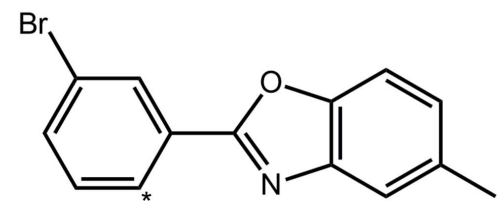



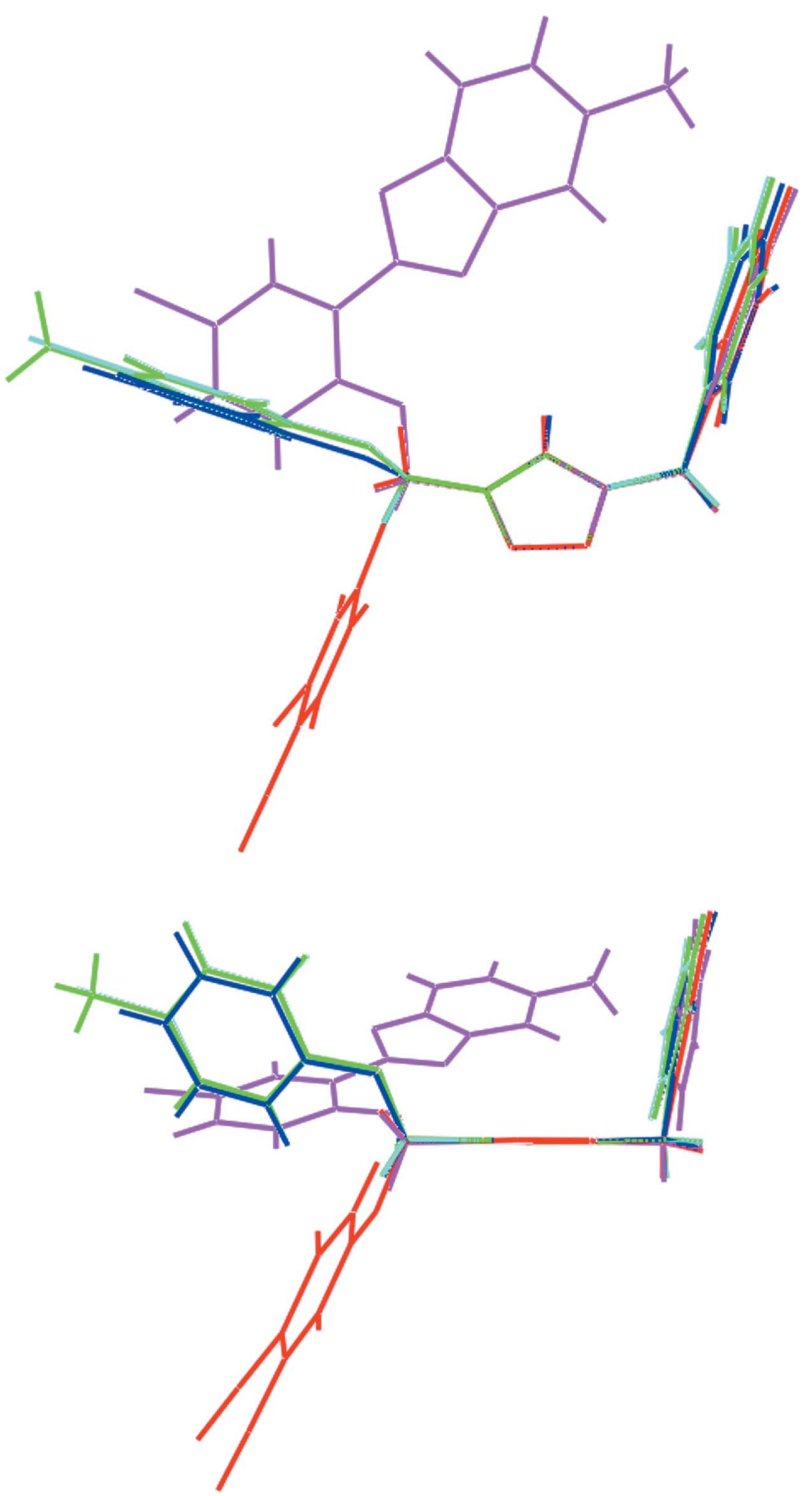

Figure 8

Two views of the different conformations in (I) red image, (II) blue, (III) green, (IV) aqua and (V) pink. The molecules have been overlapped so that the central rings are coincident.

\section{Energy-minimization calculations}

The structure of (I) was subjected to energy-minimization calculations with Density-Functional Theory (DFT) using the LC-wPBE functional (Vydrov \& Scuseria, 2006; Vydrov et al., 2006), as implemented in the Gaussian program (Frisch et al., 2009), and the exchange-hole dipole moment (XDM) dispersion correction (Becke \& Johnson, 2007; Otero-de-la-Roza \& Johnson, 2013) with the $6-31+\mathrm{G}^{*}$ basis set. Fig. 9 shows an energy profile as the 1,2 -dicarbonitrile residue is rotated $\left(30^{\circ}\right.$ steps) about the $\mathrm{O}-\mathrm{C}$ bond with respect to the rest of the molecule. The energy profile shown in Fig. 9 reveals the observed anti conformation of (I) is in fact a high-energy conformation, being nearly $7 \mathrm{kcal} \mathrm{mol}^{-1}$ higher in energy than the low-energy conformation which, as shown in Fig. 10, has a syn conformation of the aromatic rings. In the energy-mini-



Figure 9

Energy profile $\left(\mathrm{kcal} \mathrm{mol}^{-1}\right)$ for conformations of (I) differing by a rotation $\left(30^{\circ}\right.$ steps $)$ about the $\mathrm{O}-\mathrm{C}$ bond.

mized structure, the dihedral angles between the fivemembered ring and the dinitrile- and benzyl-benzene rings are 73.6 and $85.2^{\circ}$, respectively, i.e. differing by $c a 9$ and $6^{\circ}$, respectively, from the comparable angles in the experimental

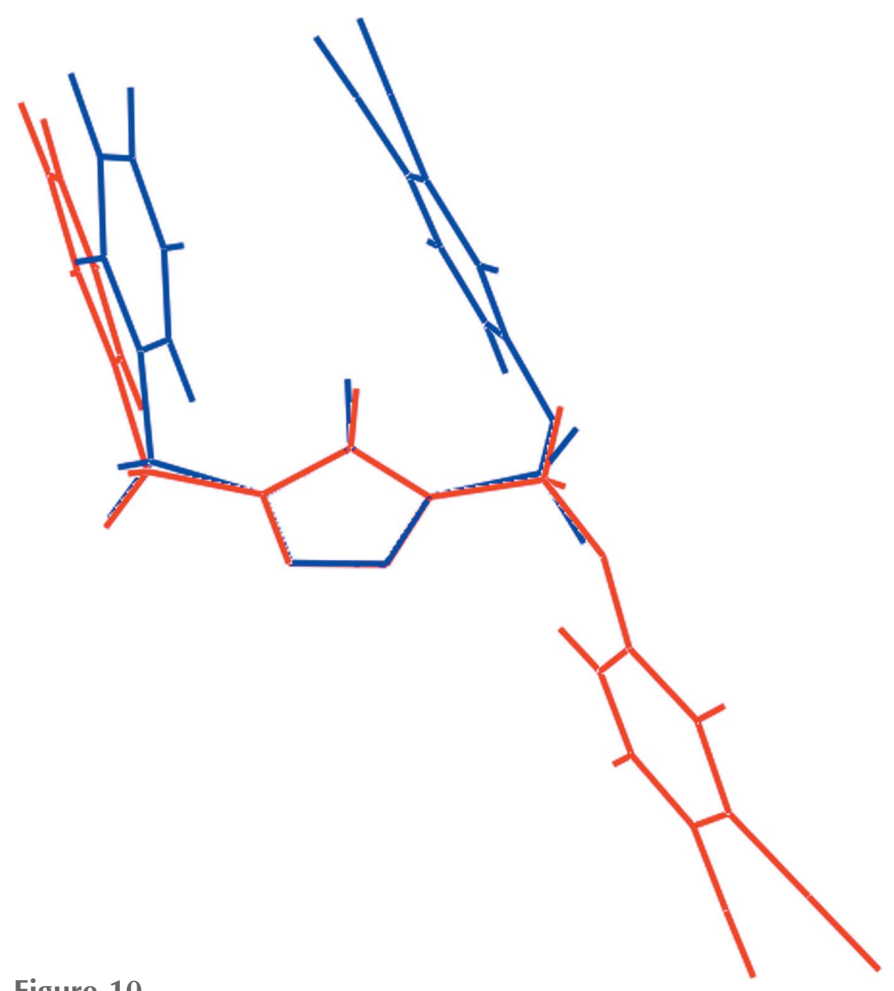

Figure 10

Overlay diagram of the experimental (red image) and energy-minimized (blue) structures of (I). The molecules have been overlapped so that the five-membered rings are coincident. 
Table 4

Experimental details.

\begin{tabular}{|c|c|}
\hline \multicolumn{2}{|l|}{ Crystal data } \\
\hline Chemical formula & $\mathrm{C}_{18} \mathrm{H}_{13} \mathrm{~N}_{5} \mathrm{O}$ \\
\hline$M_{\mathrm{r}}$ & 315.33 \\
\hline Crystal system, space group & Monoclinic, $P 2_{1} / c$ \\
\hline Temperature $(\mathrm{K})$ & 100 \\
\hline$a, b, c(\AA)$ & $5.2454(5), 15.3860(14), 19.042(3)$ \\
\hline$\beta\left(^{\circ}\right)$ & $90.927(10)$ \\
\hline$V\left(\AA^{3}\right)$ & $1536.6(3)$ \\
\hline$Z$ & 4 \\
\hline Radiation type & Мо $K \alpha$ \\
\hline$\mu\left(\mathrm{mm}^{-1}\right)$ & 0.09 \\
\hline Crystal size (mm) & $0.35 \times 0.10 \times 0.10$ \\
\hline \multicolumn{2}{|l|}{ Data collection } \\
\hline Diffractometer & $\begin{array}{l}\text { Agilent Technologies SuperNova } \\
\text { Dual diffractometer with an } \\
\text { Atlas detector }\end{array}$ \\
\hline Absorption correction & $\begin{array}{l}\text { Multi-scan (CrysAlis PRO; } \\
\text { Agilent, 2012) }\end{array}$ \\
\hline$T_{\min }, T_{\max }$ & $0.588,1.000$ \\
\hline $\begin{array}{l}\text { No. of measured, independent and } \\
\text { observed }[I>2 \sigma(I)] \text { reflections }\end{array}$ & 15856, 3527, 2099 \\
\hline$R_{\text {int }}$ & 0.080 \\
\hline$(\sin \theta / \lambda)_{\max }\left(\AA^{-1}\right)$ & 0.650 \\
\hline \multicolumn{2}{|l|}{ Refinement } \\
\hline$R\left[F^{2}>2 \sigma\left(F^{2}\right)\right], w R\left(F^{2}\right), S$ & $0.057,0.136,1.07$ \\
\hline No. of reflections & 3527 \\
\hline No. of parameters & 217 \\
\hline $\mathrm{H}$-atom treatment & $\mathrm{H}$-atom parameters constrained \\
\hline$\Delta \rho_{\max }, \Delta \rho_{\min }\left(\mathrm{e} \AA^{-3}\right)$ & $0.26,-0.25$ \\
\hline
\end{tabular}

Computer programs: CrysAlis PRO (Agilent, 2012), SHELXS97 (Sheldrick, 2008), SHELXL2014 (Sheldrick, 2015), ORTEP-3 for Windows (Farrugia, 2012), QMol (Gans \& Shalloway, 2001), DIAMOND (Brandenburg, 2006) and publCIF (Westrip, 2010).

structure. The dihedral angles between the aromatic rings is $23.4^{\circ}$. While the dihedral angles do not differ significantly between the experimental and gas-phase, energy-minimized structures, the relative conformations are quite distinct. The syn orientation of the terminal rings is most likely stabilized by intramolecular $\pi-\pi$ interactions, the shortest intramolecular C . C contact between rings being $3.62 \AA$. The adoption of a different conformation in the experimental structure no doubt relates to the dictates of global crystal packing considerations.

\section{Synthesis and crystallization}

3-(Prop-2-yn-1-yloxy)phthalonitrile (Jan et al., 2013; $0.10 \mathrm{~g}$, $0.55 \mathrm{mmol}), \mathrm{CuSO}_{4}(0.032 \mathrm{~g})$, sodium ascorbate $(0.13 \mathrm{~g})$ and benzyl azide $(0.074 \mathrm{~g})$ were dissolved in $75 \%$ aqueous acetone $(20 \mathrm{ml})$ and stirred for $48 \mathrm{~h}$ at room temperature. The reaction was poured into ice-water and the resulting off-white solid was collected by vacuum filtration and was recrystallized as light-brown prisms from a solvent mixture of dichloromethane and hexane (0.082 g, 47.5\%). M.p.: 397-399 K. IR (v) $3200 \mathrm{~m}$ (ArH), $3050 m(\mathrm{ArH}), 2226 m(\mathrm{C} \equiv \mathrm{N}), 1600 s(\mathrm{C}=\mathrm{C}, \mathrm{Ar})$. $\left[M+{ }^{\cdot}\right] \mathrm{m} / \mathrm{z} 315$.

\section{Refinement details}

Crystal data, data collection and structure refinement details are summarized in Table 4. Carbon-bound $\mathrm{H}$ atoms were placed in calculated positions $(\mathrm{C}-\mathrm{H}=0.95-0.99 \AA)$ and were included in the refinement in the riding model approximation, with $U_{\text {iso }}(\mathrm{H})$ set to $1.2 U_{\text {eq }}(\mathrm{C})$.

\section{Acknowledgements}

We acknowledge the financial support from the Brunei Research Council (BRC) Science and Technology grant (S\&T17). AOR thanks the Spanish Malta/Consolider initiative (No. CSD2007-00045) and Alberta Innovates Technology Futures (AITF) for funding. Intensity data were provided by the University of Malaya Crystallographic Laboratory.

\section{References}

Agilent (2012). CrysAlis PRO. Agilent Technologies Inc., Santa Clara, CA, USA.

Becke, A. D. \& Johnson, E. R. (2007). J. Chem. Phys. 127, 124108.

Brandenburg, K. (2006). DIAMOND. Crystal Impact GbR, Bonn, Germany.

Eberhardt, W. \& Hanack, M. (1997). Synthesis, pp. 95-100.

Farrugia, L. J. (2012). J. Appl. Cryst. 45, 849-854.

Frisch, M. J., et al. (2009). GAUSSIAN09. Gaussian Inc., Wallingford, CT, USA.

Gans, J. \& Shalloway, D. (2001). J. Mol. Graphics Modell. 19, 557-559.

Garcia, A., Rios, Z. G., Gonzalez, J., Perez, V. M., Lara, N., Fuentes, A., Gonzalez, C., Corona, D. \& Cuevas-Yanez, E. (2011). Lett. Org. Chem. 8, 701-706.

Groom, C. R. \& Allen, F. H. (2014). Angew. Chem. Int. Ed. 53, 662671.

Jan, C. Y., Shamsudin, N. B. H., Tan, A. L., Young, D. J. \& Tiekink, E. R. T. (2013). Acta Cryst. E69, o1074.

Jayatilaka, D., Grimwood, D. J., Lee, A., Lemay, A., Russel, A. J., Taylo, C., Wolff, S. K., Chenai, C. \& Whitton, A. (2005). TONTO A System for Computational Chemistry. Available at: http:// hirshfeldsurface. net/

Kitamura, T., Ikeda, M., Shigaki, K., Inoue, T., Anderson, N. A., Ai, X., Lian, T. Q. \& Yanagida, S. (2004). Chem. Mater. 16, 1806-1812.

Kolb, H. C., Finn, M. G. \& Sharpless, K. B. (2001). Angew. Chem. Int. Ed. 40, 2004-2021.

López-Ruiz, H., de la Cerda-Pedro, J. E., Rojas-Lima, S., Pérez-Pérez, I., Rodíguez-Sánchez, B. V., Santillan, R. \& Coreño, O. (2013). ARKIVOC, (iii), 139-164.

Mack, J., Kobayashi, N. \& Stillman, M. J. (2006). J. Porphyrins Phthalocyanines, 10, 1219-1237.

Nazeeruddin, M. K., Péchy, P., Renouard, T., Zakeeruddin, S. M., Humphry-Baker, R., Comte, P., Liska, P., Cevey, L., Costa, E., Shklover, V., Spiccia, L., Deacon, G. B., Bignozzi, C. A. \& Grätzel, M. (2001). J. Am. Chem. Soc. 123, 1613-1624.

Otero-de-la-Roza, A. \& Johnson, E. R. (2013). J. Chem. Phys. 138, 204109.

Rohl, A. L., Moret, M., Kaminsky, W., Claborn, K., McKinnon, J. J. \& Kahr, B. (2008). Cryst. Growth Des. 8, 4517-4525.

Rostovtsev, V. V., Green, L. G., Fokin, V. V. \& Sharpless, K. B. (2002). Angew. Chem. Int. Ed. 41, 2596-2599.

Shamsudin, N., Tan, A. L., Wimmer, F. L., Young, D. J. \& Tiekink, E. R. T. (2015). Acta Cryst. E71, 1026-1031.

Sheldrick, G. M. (2008). Acta Cryst. A64, 112-122.

Sheldrick, G. M. (2015). Acta Cryst. C71, 3-8.

Spackman, M. A., McKinnon, J. J. \& Jayatilaka, D. (2008). CrystEngComm, 10, 377-388.

Spek, A. L. (2009). Acta Cryst. D65, 148-155.

Tian, M., Wada, T., Kimura-Suda, H. \& Sasabe, H. (1997). J. Mater. Chem. 7, 861-863. 
Vydrov, O. A., Heyd, J., Krukau, A. V. \& Scuseria, G. E. (2006). J. Chem. Phys. 125, 074106.

Vydrov, O. A. \& Scuseria, G. E. (2006). J. Chem. Phys. 125, 234109.

Westrip, S. P. (2010). J. Appl. Cryst. 43, 920-925.
Wolff, S. K., Grimwood, D. J., McKinnon, J. J., Turner, M. J., Jayatilaka, D. \& Spackman, M. A. (2012). Crystal Explorer. The University of Western Australia, Australia. 


\section{supporting information}

Acta Cryst. (2016). E72, 563-569 [https://doi.org/10.1107/S2056989016004722]

\section{4-[(1-Benzyl-1H-1,2,3-triazol-4-yl)methoxy]benzene-1,2-dicarbonitrile: crystal}

\section{structure, Hirshfeld surface analysis and energy-minimization calculations}

Norzianah Shamsudin, Ai Ling Tan, David J. Young, Mukesh M. Jotani, A. Otero-de-la-Roza and

\section{Edward R. T. Tiekink}

\section{Computing details}

Data collection: CrysAlis PRO (Agilent, 2012); cell refinement: CrysAlis PRO (Agilent, 2012); data reduction: CrysAlis PRO (Agilent, 2012); program(s) used to solve structure: SHELXS97 (Sheldrick, 2008); program(s) used to refine structure: SHELXL2014 (Sheldrick, 2015); molecular graphics: ORTEP-3 for Windows (Farrugia, 2012), QMol (Gans \& Shalloway, 2001) and DIAMOND (Brandenburg, 2006); software used to prepare material for publication: publCIF (Westrip, 2010).

4-[(1-Benzyl-1 H-1,2,3-triazol-4-yl)methoxy]benzene-1,2-dicarbonitrile

Crystal data

$\mathrm{C}_{18} \mathrm{H}_{13} \mathrm{~N}_{5} \mathrm{O}$

$M_{r}=315.33$

Monoclinic, $P 2_{1} / c$

$a=5.2454(5) \AA$

$b=15.3860(14) \AA$

$c=19.042(3) \AA$

$\beta=90.927(10)^{\circ}$

$V=1536.6(3) \AA^{3}$

$Z=4$

Data collection

Agilent Technologies SuperNova Dual diffractometer with an Atlas detector

Radiation source: SuperNova (Mo) X-ray

Source

Mirror monochromator

Detector resolution: 10.4041 pixels $\mathrm{mm}^{-1}$

$\omega$ scan

Absorption correction: multi-scan

(CrysAlis PRO; Agilent, 2012)

\section{Refinement}

Refinement on $F^{2}$

Least-squares matrix: full

$R\left[F^{2}>2 \sigma\left(F^{2}\right)\right]=0.057$

$w R\left(F^{2}\right)=0.136$

$S=1.07$

3527 reflections
$F(000)=656$

$D_{\mathrm{x}}=1.363 \mathrm{Mg} \mathrm{m}^{-3}$

Mo $K \alpha$ radiation, $\lambda=0.71073 \AA$

Cell parameters from 1806 reflections

$\theta=2.5-27.5^{\circ}$

$\mu=0.09 \mathrm{~mm}^{-1}$

$T=100 \mathrm{~K}$

Prism, light-brown

$0.35 \times 0.10 \times 0.10 \mathrm{~mm}$

$T_{\min }=0.588, T_{\max }=1.000$

15856 measured reflections

3527 independent reflections

2099 reflections with $I>2 \sigma(I)$

$R_{\text {int }}=0.080$

$\theta_{\text {max }}=27.5^{\circ}, \theta_{\text {min }}=2.5^{\circ}$

$h=-6 \rightarrow 6$

$k=-19 \rightarrow 19$

$l=-24 \rightarrow 21$

217 parameters

0 restraints

Hydrogen site location: inferred from neighbouring sites

$\mathrm{H}$-atom parameters constrained 
$w=1 /\left[\sigma^{2}\left(F_{\mathrm{o}}^{2}\right)+(0.0342 P)^{2}+0.5378 P\right]$

where $P=\left(F_{\mathrm{o}}^{2}+2 F_{\mathrm{c}}{ }^{2}\right) / 3$

$(\Delta / \sigma)_{\max }<0.001$

$$
\Delta \rho_{\max }=0.26 \mathrm{e} \AA^{-3}
$$

\section{Special details}

Geometry. All esds (except the esd in the dihedral angle between two 1.s. planes) are estimated using the full covariance matrix. The cell esds are taken into account individually in the estimation of esds in distances, angles and torsion angles; correlations between esds in cell parameters are only used when they are defined by crystal symmetry. An approximate (isotropic) treatment of cell esds is used for estimating esds involving 1.s. planes.

Fractional atomic coordinates and isotropic or equivalent isotropic displacement parameters $\left(\AA^{2}\right)$

\begin{tabular}{|c|c|c|c|c|}
\hline & $x$ & $y$ & $z$ & $U_{\text {iso }} * / U_{\text {eq }}$ \\
\hline O1 & $0.3153(3)$ & $0.69488(10)$ & $0.54542(9)$ & $0.0262(4)$ \\
\hline N1 & $0.5641(4)$ & $0.50248(12)$ & $0.70174(11)$ & $0.0233(5)$ \\
\hline N2 & $0.7432(4)$ & $0.49329(13)$ & $0.65250(12)$ & $0.0294(5)$ \\
\hline N3 & $0.6509(4)$ & $0.52816(13)$ & $0.59396(11)$ & $0.0279(5)$ \\
\hline N4 & $0.7655(4)$ & $1.01212(13)$ & $0.44279(12)$ & $0.0312(5)$ \\
\hline N5 & $1.2066(4)$ & $0.86108(14)$ & $0.33358(13)$ & $0.0342(6)$ \\
\hline $\mathrm{C} 1$ & $0.3561(4)$ & $0.54262(15)$ & $0.67500(14)$ & $0.0251(6)$ \\
\hline H1 & 0.2032 & 0.5564 & 0.6987 & $0.030 *$ \\
\hline $\mathrm{C} 2$ & $0.4125(4)$ & $0.55919(14)$ & $0.60643(13)$ & $0.0216(5)$ \\
\hline $\mathrm{C} 3$ & $0.6072(5)$ & $0.46954(16)$ & $0.77327(14)$ & $0.0282(6)$ \\
\hline $\mathrm{H} 3 \mathrm{~A}$ & 0.5691 & 0.5162 & 0.8073 & $0.034 *$ \\
\hline H3B & 0.7892 & 0.4537 & 0.7794 & $0.034 *$ \\
\hline $\mathrm{C} 4$ & $0.4444(4)$ & $0.39128(15)$ & $0.78895(13)$ & $0.0234(5)$ \\
\hline $\mathrm{C} 5$ & $0.4866(4)$ & $0.31288(15)$ & $0.75402(14)$ & $0.0294(6)$ \\
\hline H5 & 0.6186 & 0.3087 & 0.7206 & $0.035^{*}$ \\
\hline C6 & $0.3363(5)$ & $0.24131(16)$ & $0.76800(15)$ & $0.0330(7)$ \\
\hline H6 & 0.3662 & 0.1880 & 0.7444 & $0.040 *$ \\
\hline $\mathrm{C} 7$ & $0.1427(5)$ & $0.24702(17)$ & $0.81622(15)$ & $0.0329(7)$ \\
\hline $\mathrm{H7}$ & 0.0388 & 0.1979 & 0.8254 & $0.040 *$ \\
\hline $\mathrm{C} 8$ & $0.1008(5)$ & $0.32439(16)$ & $0.85111(14)$ & $0.0312(6)$ \\
\hline H8 & -0.0313 & 0.3282 & 0.8845 & $0.037^{*}$ \\
\hline C9 & $0.2511(4)$ & $0.39631(16)$ & $0.83744(14)$ & $0.0273(6)$ \\
\hline H9 & 0.2213 & 0.4494 & 0.8615 & $0.033^{*}$ \\
\hline $\mathrm{C} 10$ & $0.2539(4)$ & $0.60336(14)$ & $0.55118(13)$ & $0.0240(6)$ \\
\hline $\mathrm{H} 10 \mathrm{~A}$ & 0.2818 & 0.5747 & 0.5054 & $0.029 *$ \\
\hline H10B & 0.0714 & 0.5970 & 0.5626 & $0.029 *$ \\
\hline $\mathrm{C} 11$ & 0.5055 & $0.72062(15)$ & $0.50218(13)$ & $0.0224(5)$ \\
\hline $\mathrm{C} 12$ & $0.5349(4)$ & $0.81069(15)$ & $0.49807(13)$ & $0.0227(5)$ \\
\hline H12 & 0.4294 & 0.8480 & 0.5248 & $0.027^{*}$ \\
\hline $\mathrm{C} 13$ & $0.7180(4)$ & $0.84514(14)$ & $0.45502(13)$ & $0.0224(5)$ \\
\hline $\mathrm{C} 14$ & 0.8748 & $0.79094(15)$ & $0.41502(13)$ & $0.0227(5)$ \\
\hline C15 & $0.8425(4)$ & $0.70107(15)$ & $0.41989(13)$ & $0.0254(6)$ \\
\hline H15 & 0.9464 & 0.6635 & 0.3929 & $0.031^{*}$ \\
\hline C16 & $0.6609(4)$ & $0.66612(15)$ & $0.46354(13)$ & $0.0236(5)$ \\
\hline H16 & 0.6425 & 0.6049 & 0.4671 & $0.028 *$ \\
\hline $\mathrm{C} 17$ & $0.7433(4)$ & $0.93813(16)$ & $0.44910(13)$ & $0.0240(6)$ \\
\hline
\end{tabular}


Atomic displacement parameters $\left(\AA^{2}\right)$

\begin{tabular}{lllllll}
\hline & $U^{11}$ & $U^{22}$ & $U^{33}$ & $U^{12}$ & $U^{13}$ & $U^{23}$ \\
\hline O1 & $0.0306(9)$ & $0.0188(9)$ & $0.0296(11)$ & $0.0005(7)$ & $0.0083(8)$ & $0.0045(8)$ \\
N1 & $0.0236(10)$ & $0.0228(11)$ & $0.0236(12)$ & $-0.0017(8)$ & $0.0033(9)$ & $0.0012(9)$ \\
N2 & $0.0230(10)$ & $0.0349(12)$ & $0.0305(14)$ & $0.0018(9)$ & $0.0057(10)$ & $0.0039(10)$ \\
N3 & $0.0262(11)$ & $0.0301(12)$ & $0.0276(13)$ & $0.0001(9)$ & $0.0053(9)$ & $0.0031(10)$ \\
N4 & $0.0359(12)$ & $0.0237(12)$ & $0.0344(14)$ & $0.0005(9)$ & $0.0068(10)$ & $0.0009(10)$ \\
N5 & $0.0384(12)$ & $0.0288(12)$ & $0.0358(15)$ & $-0.0041(10)$ & $0.0103(11)$ & $0.0015(11)$ \\
C1 & $0.0237(12)$ & $0.0227(13)$ & $0.0291(16)$ & $0.0034(10)$ & $0.0055(11)$ & $-0.0006(11)$ \\
C2 & $0.0211(11)$ & $0.0152(12)$ & $0.0285(15)$ & $-0.0037(9)$ & $0.0044(10)$ & $-0.0014(10)$ \\
C3 & $0.0300(13)$ & $0.0289(14)$ & $0.0256(15)$ & $-0.0009(10)$ & $-0.0024(11)$ & $0.0036(12)$ \\
C4 & $0.0228(12)$ & $0.0229(13)$ & $0.0245(15)$ & $0.0035(10)$ & $-0.0023(10)$ & $0.0018(11)$ \\
C5 & $0.0282(13)$ & $0.0287(14)$ & $0.0314(16)$ & $0.0054(10)$ & $0.0033(11)$ & $0.0000(12)$ \\
C6 & $0.0425(15)$ & $0.0220(14)$ & $0.0344(17)$ & $0.0023(11)$ & $-0.0022(13)$ & $0.0018(12)$ \\
C7 & $0.0365(14)$ & $0.0250(14)$ & $0.0371(18)$ & $-0.0042(11)$ & $-0.0027(13)$ & $0.0105(12)$ \\
C8 & $0.0274(13)$ & $0.0352(16)$ & $0.0310(16)$ & $-0.0002(11)$ & $0.0017(11)$ & $0.0055(13)$ \\
C9 & $0.0268(12)$ & $0.0261(13)$ & $0.0291(16)$ & $0.0032(10)$ & $0.0015(11)$ & $0.0002(12)$ \\
C10 & $0.0266(12)$ & $0.0192(12)$ & $0.0265(15)$ & $-0.0036(9)$ & $0.0057(11)$ & $0.0030(11)$ \\
C11 & $0.0215(11)$ & $0.0247(13)$ & $0.0211(14)$ & $-0.0030(9)$ & $-0.0007(10)$ & $0.0056(11)$ \\
C12 & $0.0239(12)$ & $0.0210(12)$ & $0.0233(14)$ & $0.0024(9)$ & $0.0017(10)$ & $-0.0007(10)$ \\
C13 & $0.0254(12)$ & $0.0193(12)$ & $0.0224(14)$ & $-0.0001(9)$ & $-0.0014(10)$ & $0.0007(10)$ \\
C14 & $0.0256(12)$ & $0.0215(13)$ & $0.0209(14)$ & $-0.0014(10)$ & $0.0019(10)$ & $0.0023(10)$ \\
C15 & $0.0279(12)$ & $0.0239(13)$ & $0.0247(15)$ & $0.0021(10)$ & $0.0039(11)$ & $-0.0021(11)$ \\
C16 & $0.0293(12)$ & $0.0181(12)$ & $0.0237(15)$ & $-0.0010(10)$ & $0.0052(11)$ & $0.0002(11)$ \\
C17 & $0.0223(12)$ & $0.0279(14)$ & $0.0219(14)$ & $0.0011(10)$ & $0.0040(10)$ & $0.0000(11)$ \\
C18 & $0.0279(13)$ & $0.0217(13)$ & $0.0272(16)$ & $0.0014(10)$ & $-0.0004(12)$ & $-0.0006(11)$ \\
& & & & & & \\
\hline & & & & & &
\end{tabular}

Geometric parameters $\left(\AA,{ }^{\circ}\right)$

\begin{tabular}{llll}
\hline $\mathrm{O} 1-\mathrm{C} 11$ & $1.363(3)$ & $\mathrm{C} 6-\mathrm{H} 6$ & 0.9500 \\
$\mathrm{O} 1-\mathrm{C} 10$ & $1.449(3)$ & $\mathrm{C} 7-\mathrm{C} 8$ & $1.382(4)$ \\
$\mathrm{N} 1-\mathrm{N} 2$ & $1.346(3)$ & $\mathrm{C} 7-\mathrm{H} 7$ & 0.9500 \\
$\mathrm{~N} 1-\mathrm{C} 1$ & $1.347(3)$ & $\mathrm{C} 8-\mathrm{C} 9$ & $1.386(3)$ \\
$\mathrm{N} 1-\mathrm{C} 3$ & $1.467(3)$ & $\mathrm{C} 8-\mathrm{H} 8$ & 0.9500 \\
$\mathrm{~N} 2-\mathrm{N} 3$ & $1.322(3)$ & $\mathrm{C} 9-\mathrm{H} 9$ & 0.9500 \\
$\mathrm{~N} 3-\mathrm{C} 2$ & $1.363(3)$ & $\mathrm{C} 10-\mathrm{H} 10 \mathrm{~A}$ & 0.9900 \\
$\mathrm{~N} 4-\mathrm{C} 17$ & $1.151(3)$ & $\mathrm{C} 10-\mathrm{H} 10 \mathrm{~B}$ & 0.9900 \\
$\mathrm{~N} 5-\mathrm{C} 18$ & $1.149(3)$ & $\mathrm{C} 11-\mathrm{C} 16$ & $1.388(3)$ \\
$\mathrm{C} 1-\mathrm{C} 2$ & $1.367(3)$ & $\mathrm{C} 11-\mathrm{C} 12$ & $1.397(3)$ \\
$\mathrm{C} 1-\mathrm{H} 1$ & 0.9500 & $\mathrm{C} 12-\mathrm{C} 13$ & $1.379(3)$ \\
$\mathrm{C} 2-\mathrm{C} 10$ & $1.494(3)$ & $\mathrm{C} 12-\mathrm{H} 12$ & 0.9500 \\
$\mathrm{C} 3-\mathrm{C} 4$ & $1.509(3)$ & $\mathrm{C} 13-\mathrm{C} 14$ & $1.404(3)$ \\
$\mathrm{C} 3-\mathrm{H} 3 \mathrm{~A}$ & 0.9900 & $\mathrm{C} 13-\mathrm{C} 17$ & $1.441(3)$ \\
$\mathrm{C} 3-\mathrm{H} 3 \mathrm{~B}$ & 0.9900 & $\mathrm{C} 14-\mathrm{C} 15$ & $1.396(3)$ \\
$\mathrm{C} 4-\mathrm{C} 9$ & $1.385(3)$ & $\mathrm{C} 14-\mathrm{C} 18$ & $1.437(4)$
\end{tabular}




\begin{tabular}{|c|c|c|c|}
\hline $\mathrm{C} 4-\mathrm{C} 5$ & $1.397(3)$ & $\mathrm{C} 15-\mathrm{C} 16$ & $1.383(3)$ \\
\hline $\mathrm{C} 5-\mathrm{C} 6$ & $1.383(3)$ & C15-H15 & 0.9500 \\
\hline $\mathrm{C} 5-\mathrm{H} 5$ & 0.9500 & $\mathrm{C} 16-\mathrm{H} 16$ & 0.9500 \\
\hline $\mathrm{C} 6-\mathrm{C} 7$ & $1.383(4)$ & & \\
\hline $\mathrm{C} 11-\mathrm{O} 1-\mathrm{C} 10$ & $119.61(18)$ & $\mathrm{C} 7-\mathrm{C} 8-\mathrm{H} 8$ & 119.9 \\
\hline $\mathrm{N} 2-\mathrm{N} 1-\mathrm{C} 1$ & $110.8(2)$ & $\mathrm{C} 9-\mathrm{C} 8-\mathrm{H} 8$ & 119.9 \\
\hline $\mathrm{N} 2-\mathrm{N} 1-\mathrm{C} 3$ & $120.75(19)$ & $\mathrm{C} 4-\mathrm{C} 9-\mathrm{C} 8$ & $120.4(2)$ \\
\hline $\mathrm{C} 1-\mathrm{N} 1-\mathrm{C} 3$ & $128.4(2)$ & $\mathrm{C} 4-\mathrm{C} 9-\mathrm{H} 9$ & 119.8 \\
\hline $\mathrm{N} 3-\mathrm{N} 2-\mathrm{N} 1$ & $107.14(18)$ & $\mathrm{C} 8-\mathrm{C} 9-\mathrm{H} 9$ & 119.8 \\
\hline $\mathrm{N} 2-\mathrm{N} 3-\mathrm{C} 2$ & $108.6(2)$ & $\mathrm{O} 1-\mathrm{C} 10-\mathrm{C} 2$ & $111.92(17)$ \\
\hline $\mathrm{N} 1-\mathrm{C} 1-\mathrm{C} 2$ & $105.1(2)$ & $\mathrm{O} 1-\mathrm{C} 10-\mathrm{H} 10 \mathrm{~A}$ & 109.2 \\
\hline $\mathrm{N} 1-\mathrm{C} 1-\mathrm{H} 1$ & 127.5 & $\mathrm{C} 2-\mathrm{C} 10-\mathrm{H} 10 \mathrm{~A}$ & 109.2 \\
\hline $\mathrm{C} 2-\mathrm{C} 1-\mathrm{H} 1$ & 127.5 & $\mathrm{O} 1-\mathrm{C} 10-\mathrm{H} 10 \mathrm{~B}$ & 109.2 \\
\hline $\mathrm{N} 3-\mathrm{C} 2-\mathrm{C} 1$ & $108.3(2)$ & $\mathrm{C} 2-\mathrm{C} 10-\mathrm{H} 10 \mathrm{~B}$ & 109.2 \\
\hline $\mathrm{N} 3-\mathrm{C} 2-\mathrm{C} 10$ & $122.6(2)$ & $\mathrm{H} 10 \mathrm{~A}-\mathrm{C} 10-\mathrm{H} 10 \mathrm{~B}$ & 107.9 \\
\hline $\mathrm{C} 1-\mathrm{C} 2-\mathrm{C} 10$ & $129.1(2)$ & $\mathrm{O} 1-\mathrm{C} 11-\mathrm{C} 16$ & $125.9(2)$ \\
\hline $\mathrm{N} 1-\mathrm{C} 3-\mathrm{C} 4$ & $112.33(19)$ & $\mathrm{O} 1-\mathrm{C} 11-\mathrm{C} 12$ & $113.9(2)$ \\
\hline $\mathrm{N} 1-\mathrm{C} 3-\mathrm{H} 3 \mathrm{~A}$ & 109.1 & $\mathrm{C} 16-\mathrm{C} 11-\mathrm{C} 12$ & $120.2(2)$ \\
\hline $\mathrm{C} 4-\mathrm{C} 3-\mathrm{H} 3 \mathrm{~A}$ & 109.1 & $\mathrm{C} 13-\mathrm{C} 12-\mathrm{C} 11$ & $119.6(2)$ \\
\hline $\mathrm{N} 1-\mathrm{C} 3-\mathrm{H} 3 \mathrm{~B}$ & 109.1 & $\mathrm{C} 13-\mathrm{C} 12-\mathrm{H} 12$ & 120.2 \\
\hline $\mathrm{C} 4-\mathrm{C} 3-\mathrm{H} 3 \mathrm{~B}$ & 109.1 & $\mathrm{C} 11-\mathrm{C} 12-\mathrm{H} 12$ & 120.2 \\
\hline $\mathrm{H} 3 \mathrm{~A}-\mathrm{C} 3-\mathrm{H} 3 \mathrm{~B}$ & 107.9 & $\mathrm{C} 12-\mathrm{C} 13-\mathrm{C} 14$ & $120.9(2)$ \\
\hline $\mathrm{C} 9-\mathrm{C} 4-\mathrm{C} 5$ & $119.3(2)$ & $\mathrm{C} 12-\mathrm{C} 13-\mathrm{C} 17$ & $119.6(2)$ \\
\hline $\mathrm{C} 9-\mathrm{C} 4-\mathrm{C} 3$ & $120.7(2)$ & $\mathrm{C} 14-\mathrm{C} 13-\mathrm{C} 17$ & $119.4(2)$ \\
\hline $\mathrm{C} 5-\mathrm{C} 4-\mathrm{C} 3$ & $120.0(2)$ & $\mathrm{C} 15-\mathrm{C} 14-\mathrm{C} 13$ & $118.6(2)$ \\
\hline $\mathrm{C} 6-\mathrm{C} 5-\mathrm{C} 4$ & $120.1(3)$ & $\mathrm{C} 15-\mathrm{C} 14-\mathrm{C} 18$ & $121.4(2)$ \\
\hline $\mathrm{C} 6-\mathrm{C} 5-\mathrm{H} 5$ & 120.0 & $\mathrm{C} 13-\mathrm{C} 14-\mathrm{C} 18$ & $119.9(2)$ \\
\hline $\mathrm{C} 4-\mathrm{C} 5-\mathrm{H} 5$ & 120.0 & $\mathrm{C} 16-\mathrm{C} 15-\mathrm{C} 14$ & $120.7(2)$ \\
\hline $\mathrm{C} 5-\mathrm{C} 6-\mathrm{C} 7$ & $120.3(3)$ & $\mathrm{C} 16-\mathrm{C} 15-\mathrm{H} 15$ & 119.7 \\
\hline $\mathrm{C} 5-\mathrm{C} 6-\mathrm{H} 6$ & 119.9 & $\mathrm{C} 14-\mathrm{C} 15-\mathrm{H} 15$ & 119.7 \\
\hline $\mathrm{C} 7-\mathrm{C} 6-\mathrm{H} 6$ & 119.9 & $\mathrm{C} 15-\mathrm{C} 16-\mathrm{C} 11$ & $120.0(2)$ \\
\hline $\mathrm{C} 8-\mathrm{C} 7-\mathrm{C} 6$ & $119.9(2)$ & $\mathrm{C} 15-\mathrm{C} 16-\mathrm{H} 16$ & 120.0 \\
\hline $\mathrm{C} 8-\mathrm{C} 7-\mathrm{H} 7$ & 120.1 & $\mathrm{C} 11-\mathrm{C} 16-\mathrm{H} 16$ & 120.0 \\
\hline $\mathrm{C} 6-\mathrm{C} 7-\mathrm{H} 7$ & 120.1 & $\mathrm{~N} 4-\mathrm{C} 17-\mathrm{C} 13$ & $178.4(3)$ \\
\hline $\mathrm{C} 7-\mathrm{C} 8-\mathrm{C} 9$ & $120.1(3)$ & $\mathrm{N} 5-\mathrm{C} 18-\mathrm{C} 14$ & 177.7 (3) \\
\hline $\mathrm{C} 1-\mathrm{N} 1-\mathrm{N} 2-\mathrm{N} 3$ & $0.4(2)$ & $\mathrm{C} 7-\mathrm{C} 8-\mathrm{C} 9-\mathrm{C} 4$ & $-0.1(4)$ \\
\hline $\mathrm{C} 3-\mathrm{N} 1-\mathrm{N} 2-\mathrm{N} 3$ & $179.53(19)$ & $\mathrm{C} 11-\mathrm{O} 1-\mathrm{C} 10-\mathrm{C} 2$ & $87.8(2)$ \\
\hline $\mathrm{N} 1-\mathrm{N} 2-\mathrm{N} 3-\mathrm{C} 2$ & $-0.2(2)$ & $\mathrm{N} 3-\mathrm{C} 2-\mathrm{C} 10-\mathrm{O} 1$ & $-84.1(3)$ \\
\hline $\mathrm{N} 2-\mathrm{N} 1-\mathrm{C} 1-\mathrm{C} 2$ & $-0.5(3)$ & $\mathrm{C} 1-\mathrm{C} 2-\mathrm{C} 10-\mathrm{O} 1$ & $95.6(3)$ \\
\hline $\mathrm{C} 3-\mathrm{N} 1-\mathrm{C} 1-\mathrm{C} 2$ & $-179.5(2)$ & $\mathrm{C} 10-\mathrm{O} 1-\mathrm{C} 11-\mathrm{C} 16$ & $-3.0(3)$ \\
\hline $\mathrm{N} 2-\mathrm{N} 3-\mathrm{C} 2-\mathrm{C} 1$ & $-0.1(3)$ & $\mathrm{C} 10-\mathrm{O} 1-\mathrm{C} 11-\mathrm{C} 12$ & $176.24(18)$ \\
\hline $\mathrm{N} 2-\mathrm{N} 3-\mathrm{C} 2-\mathrm{C} 10$ & $179.62(19)$ & $\mathrm{O} 1-\mathrm{C} 11-\mathrm{C} 12-\mathrm{C} 13$ & $-178.81(19)$ \\
\hline $\mathrm{N} 1-\mathrm{C} 1-\mathrm{C} 2-\mathrm{N} 3$ & $0.4(3)$ & $\mathrm{C} 16-\mathrm{C} 11-\mathrm{C} 12-\mathrm{C} 13$ & $0.5(3)$ \\
\hline $\mathrm{N} 1-\mathrm{C} 1-\mathrm{C} 2-\mathrm{C} 10$ & $-179.4(2)$ & $\mathrm{C} 11-\mathrm{C} 12-\mathrm{C} 13-\mathrm{C} 14$ & $0.2(3)$ \\
\hline $\mathrm{N} 2-\mathrm{N} 1-\mathrm{C} 3-\mathrm{C} 4$ & $-109.4(2)$ & $\mathrm{C} 11-\mathrm{C} 12-\mathrm{C} 13-\mathrm{C} 17$ & $178.1(2)$ \\
\hline $\mathrm{C} 1-\mathrm{N} 1-\mathrm{C} 3-\mathrm{C} 4$ & $69.6(3)$ & $\mathrm{C} 12-\mathrm{C} 13-\mathrm{C} 14-\mathrm{C} 15$ & $-0.3(3)$ \\
\hline
\end{tabular}




\begin{tabular}{llll}
$\mathrm{N} 1-\mathrm{C} 3-\mathrm{C} 4-\mathrm{C} 9$ & $-112.3(3)$ & $\mathrm{C} 17-\mathrm{C} 13-\mathrm{C} 14-\mathrm{C} 15$ & $-178.2(2)$ \\
$\mathrm{N} 1-\mathrm{C} 3-\mathrm{C} 4-\mathrm{C} 5$ & $67.2(3)$ & $\mathrm{C} 12-\mathrm{C} 13-\mathrm{C} 14-\mathrm{C} 18$ & $178.7(2)$ \\
$\mathrm{C} 9-\mathrm{C} 4-\mathrm{C} 5-\mathrm{C} 6$ & $0.0(3)$ & $\mathrm{C} 17-\mathrm{C} 13-\mathrm{C} 14-\mathrm{C} 18$ & $0.8(3)$ \\
$\mathrm{C} 3-\mathrm{C} 4-\mathrm{C} 5-\mathrm{C} 6$ & $-179.5(2)$ & $\mathrm{C} 13-\mathrm{C} 14-\mathrm{C} 15-\mathrm{C} 16$ & $-0.4(3)$ \\
$\mathrm{C} 4-\mathrm{C} 5-\mathrm{C} 6-\mathrm{C} 7$ & $0.4(4)$ & $\mathrm{C} 18-\mathrm{C} 14-\mathrm{C} 15-\mathrm{C} 16$ & $-179.4(2)$ \\
$\mathrm{C} 5-\mathrm{C} 6-\mathrm{C} 7-\mathrm{C} 8$ & $-0.6(4)$ & $\mathrm{C} 14-\mathrm{C} 15-\mathrm{C} 16-\mathrm{C} 11$ & $1.1(3)$ \\
$\mathrm{C} 6-\mathrm{C} 7-\mathrm{C} 8-\mathrm{C} 9$ & $0.5(4)$ & $\mathrm{O} 1-\mathrm{C} 11-\mathrm{C} 16-\mathrm{C} 15$ & $178.1(2)$ \\
$\mathrm{C} 5-\mathrm{C} 4-\mathrm{C} 9-\mathrm{C} 8$ & $-0.1(3)$ & $\mathrm{C} 12-\mathrm{C} 11-\mathrm{C} 16-\mathrm{C} 15$ & $-1.1(3)$ \\
$\mathrm{C} 3-\mathrm{C} 4-\mathrm{C} 9-\mathrm{C} 8$ & $179.4(2)$ & & \\
\hline
\end{tabular}

Hydrogen-bond geometry $\left(A,{ }^{\circ}\right)$

$\mathrm{Cg} 1$ is the centroid of the $\mathrm{C} 11-\mathrm{C} 16$ ring.

\begin{tabular}{lllll}
\hline$D-\mathrm{H} \cdots A$ & $D-\mathrm{H}$ & $\mathrm{H} \cdots A$ & $D \cdots A$ & $D-\mathrm{H} \cdots A$ \\
\hline $\mathrm{C} 10-\mathrm{H} 10 A \cdots \mathrm{N} 3^{\mathrm{i}}$ & 0.99 & 2.50 & $3.468(3)$ & 167 \\
$\mathrm{C} 10-\mathrm{H} 10 B \cdots \mathrm{N} 3^{\mathrm{ii}}$ & 0.99 & 2.53 & $3.477(3)$ & 161 \\
$\mathrm{C} 12-\mathrm{H} 12 \cdots \mathrm{N} 4^{\mathrm{iii}}$ & 0.95 & 2.47 & $3.353(3)$ & 155 \\
$\mathrm{C} 18-\mathrm{N} 5 \cdots \mathrm{Cg} 1^{\mathrm{ii}}$ & $1.15(1)$ & $3.81(1)$ & $3.853(2)$ & $83(1)$
\end{tabular}

Symmetry codes: (i) $-x+1,-y+1,-z+1$; (ii) $x-1, y, z$; (iii) $-x+1,-y+2,-z+1$; (iv) $x+1, y, z$. 